\title{
FEDERAL CONTRACTOR LIABILITY: THE HANFORD DECISION
}

\author{
Caitlin Goetz;
}

\section{INTRODUCTION}

During World War II, the U.S. Government sought out contractors in the name of "patriotism" to research and develop nuclear materials for this country's defense. Nearly seventy years later, we are still dealing with the effects of that research. However, the issue of who should bear responsibility for the long-term effects is still being argued. One of the major issues is whether those contractors are allowed to raise the federal contractor defense.

The common law federal contractor defense arises out of basic principles of governmental immunity. The defense protects government contractors from liability for any harm arising out the performance of a government contract, specifically in the areas of military and defense work, if the contractor was following the government's directions and the work performed was in an area of "uniquely federal" concern.

The issue of application of federal contractor liability defense has most recently been addressed in the Hanford litigation. ${ }^{1}$ The Hanford litigation stems from the long-term effects of the production of plutonium in Hanford, Washington by various contractors during World War Two. E.I. DuPont, a corporate defendant in the Hanford litigation, attempted to utilize the government contractor defense to seek dismissal from the suit. The Ninth Circuit held that the Price-Anderson Act preempts the federal government contractor defense and therefore E.I. DuPont could not be dismissed from the Hanford litigation.

Following a brief overview of the Price-Anderson Act and the Hanford litigation, this note will detail the weaknesses in the Ninth's Circuit's reasoning regarding the application of the federal contractor defense. The

\footnotetext{
* Caitlin Goetz graduated from the University of Pittsburgh School of Law on May 13, 2011. She received a B.A. in political science with a minor in economics from the Pennsylvania State University in 2007. She would like to thank the staff for all of their work and input on this note.

1. In re Hanford Nuclear Reservation Litig., 534 F.3d 986 (9th Cir. 2008), cert. denied, 129 S. Ct. $762(2008)$
} 
federal contractor defense should be applied in the Hanford case because it existed prior to the Price-Anderson Act's 1988 amendments and does not contradict the purpose of the Price-Anderson Act. Additionally, there are serious issues with the nuclear industry that should be considered before denying application of this defense to contractors like E.I. DuPont.

\section{The Bigger Picture: Why Application of This Defense in This CASE IS IMPORTANT}

Nuclear energy is a hot topic in the United States today. With a new emphasis on environmentalism, the issue will only become more prominent. However, there are many obstacles in the way of pushing forward with this environmentally friendly, carbon-free form of energy. Nuclear waste, funding, heavy regulation, and public perception are all major players in the future of nuclear energy.

The nuclear industry is one of the most highly regulated industries in the country. The U.S. Department of Energy has ultimate responsibility for regulating the nuclear industry through the Nuclear Regulatory Commission (NRC). ${ }^{2}$ Each year, the NRC awards about $\$ 80,000,000$ in contracts to private entities. ${ }^{3}$ However, the number of companies involved in the nuclear industry

is rather small. There are only 25 different operators of nuclear power plants in the U.S. today. ${ }^{4}$

Even the courts that decided Hanford do not contest that the nuclear industry is one of the most highly regulated industries in the country. The Ninth Circuit clearly stated that "[i]t is not disputed that the federal government is in charge of nuclear safety." The court also states that "the safety of nuclear technology [is] exclusively the business of the Federal Government,' which has 'occupied the entire field of nuclear safety concerns." "These assertions are not unfounded. There is a long history of regulation of the nuclear industry. The federal government made the first developments in nuclear power and technologies. ${ }^{7}$ It was not until 1954 that

\footnotetext{
2. United States Nuclear Regulatory Commission, How We Regulate, http://www.nrc.gov/ about-nrc/regulatory.html (updated Jan. 2011)

3. United States Nuclear Regulatory Commission, Contracting Opportunities, http://www.nrc.gov/ about-nrc/contracting.html (updated Jan. 2011).

4. World Nuclear Association, Nuclear Power in the U.S.A., http://www.world-nuclear.org/ info/inf41.html (updated Dec. 28, 2010).

5. Hanford, 534 F.3d at 1003.

6. Id.

7. Annemarie Wall, Going Nowhere in the Nuke of Time: Breach of the Yucca Contract, Nuclear
} 
the federal government encouraged civilian participation in the nuclear industry under the Atomic Energy Act. ${ }^{8}$ However, this Act did not give control to private companies as $\S 161$ of the Atomic Energy Act vested all regulation authority over the industry in an agency of the federal government, the Atomic Energy Commission, and gave the Department of Energy the authority to set radiation standards for nuclear power generators. ${ }^{9}$ Later, in yet another attempt to encourage civilian participation in the industry, the Price-Anderson Act was enacted to limit potential liability. ${ }^{10}$

To balance environmental concerns with the economic aspects of the industry, the National Environmental Policy Act ${ }^{11}$ was enacted in 1969 to enforce environmental regulations on the nuclear industry. ${ }^{12}$ In 1974, Congress did away with the Atomic Energy Commission and created both the Energy Research and Development Administration and the Nuclear Regulatory Commission, granting each different regulatory duties. ${ }^{13}$ Finally, in 1980, the Nuclear Waste Policy Act was passed to address the problem of nuclear waste disposal. ${ }^{14}$ Under this Act, the federal government committed itself to providing a solution to the permanent disposal of commercial generator's nuclear waste. ${ }^{15}$ Yucca Mountain was chosen as the government's permanent disposal. ${ }^{16}$ Once the Yucca Mountain facility is completed, the Department of Energy plans to take title to the commercial nuclear waste and manage its disposal. ${ }^{17}$ To date, the federal government has failed to fulfill its obligations under the Nuclear Waste Policy Act and has been sued regarding its breach of contract and has lost, with the courts rejecting its excuses and holding the government liable for all damages caused by the excessive delays in the completion of Yucca Mountain. ${ }^{18}$

The history detailed above portrays an industry that faces government interference, regulation, and oversight in nearly every aspect. With so much at stake, there will be tension between commercial entities, industry

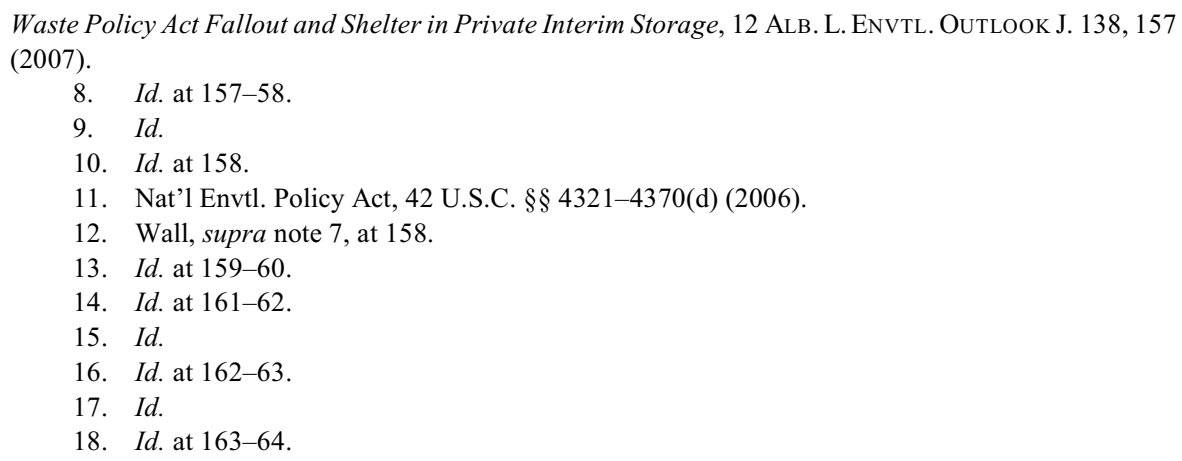


contractors, and federal government. When both private companies and the federal government work together under the heavy regulation of the federal government and for the sole purposes of federal government use, it must be clear who will bear the responsibility for the risks. Any potential contractor who signs on to work with the federal government for non-energy, strictly governmental nuclear purposes needs to know before agreeing to work whether they will be responsible for damages should any liability arise.

Additionally, the public needs a clearer distinction between the federal government nuclear industry and the private commercial nuclear energy industry. So many fears regarding nuclear energy actually stem from nuclear weapons. ${ }^{19}$ However, nuclear weapons and nuclear energy are not the same thing. Nuclear weapons and nuclear energy require different formulas or fuel, as well as different production. ${ }^{20}$ This is not to say that the public should be denied some form of protection in case there is a nuclear accident, but the roles and responsibility of the private commercial sector and the federal government need to be clearly distinguished for everyone involved, especially the public.

\section{The Price-Anderson Act}

In 1957, Congress enacted the "Price-Anderson Act" (PAA) as an amendment to the Atomic Energy Act, to ensure the availability of "a large pool of funds to provide for prompt and orderly compensation of members of the public who incur damages from a nuclear or radiological incident no matter who might be liable." ${ }^{21}$ The PAA requires indemnification contracts for personal injury and property damage. ${ }^{22}$ This Act covers any party that may be legally liable. Therefore a claimant can directly sue a licensee or contractor after a nuclear accident. ${ }^{23}$ The PAA covers operation of power reactors, research reactors, the Department of Energy's nuclear and radiological facilities, and the transportation of nuclear fuel from any one of these

19. See Greenpeace, End the Nuclear Age, Greenpeace, http://www.greenpeace.org/international/ campaigns/nuclear (last visited Jan. 30, 2011); see also Stephen Koff, "Peaceful" Nuclear Power Fuels Spread of Weapons, Clev. Plain Dealer Apr. 23, 2003, available at http://www.commondreams.org/ headlines03/0427-02.htm.

20. Andrew Karam, The Difference between a Nuclear Reactor and a Nuclear Bomb, MADSCI Network (May 2, 2001, 4:38 PM), http://www.madsci.org/posts/archives/2001-05/988836248.Ph.r.html.

21. Am. Nuclear Soc'y, The Price-Anderson Act: Background Information 1, Nov. 2005, www.ans.org/pi/ps/docs/ps54-bi.pdf.

22. $I d$.

23. $I d$. 


\section{facilities. $^{24}$}

The PAA creates a scheme of insurance pooling, which pools contributions from all licensed nuclear facilities and requires facilities to secure private insurance to ensure that sufficient funds are readily available to pay for any nuclear accident. ${ }^{25}$ This method spreads the risk over a "large financial base." ${ }^{26}$ The PAA also includes indemnifications by the DOE. ${ }^{27}$

This DOE indemnification: (1) provides omnibus coverage of all persons who might be legally liable; (2) indemnifies fully all legal liability up to the statutory limit on such liability (currently $\$ 9.43$ billion for a nuclear incident in the United States); (3) covers all DOE contractual activity that might result in a nuclear incident in the United States;

(4) is not subject to the usual limitation on the availability of appropriated funds; and

(5) is mandatory and exclusive. ${ }^{28}$

However, it was not until the 1988 amendments to the PAA that such indemnification was mandatory. ${ }^{29}$ Prior to 1988 , whether to provide indemnification for contractors was up to the discretion of the DOE. ${ }^{30}$ As of 2005 , insurance pools have paid $\$ 151$ million in claims, and the Department of Energy (DOE) has only paid $\$ 65$ million. ${ }^{31}$ In 2005 , the Price-Anderson Act was renewed until 2025. ${ }^{32}$

\section{IN RE HANFORD NUCLEAR RESERVATION LITIGATION}

\section{A. Overview of the Case}

The Hanford case begins with the Manhattan Project during World War Two. ${ }^{33}$ The Hanford facility, located in eastern Washington, was built to

24. Id.

25. Id. at 2 .

26. Id. at $2-3$.

27. Dep't of Energy, Report to Congress on the Price-Anderson Act, March 1999, www.gc.energy.gov/documents/paa-rep.pdf (last visited Feb. 25, 2010).

28. Id.

29. Dep't of Energy, Notice of Inquiry: Preparation of Report to Congress on Price-Anderson Act, Dec. 23, 1997, http://www.gc.energy.gov/notice_of_inquiry.htm (last visited Mar. 2, 2011); see also Am. Nuclear Soc'y, supra note 21, at 1.

30. $I d$.

31. Am. Nuclear Soc'y, supra note 21, at 3.

32. Nuclear Energy Inst., Fact Sheet: Price-Anderson Act Provides Effective Liability Insurance at No Cost to the Public 2-3 (Aug. 2009), http://www.nei.org/filefolder/Price-Anderson_Act_Provides_ Effective_Liability_Insurance_at_No_Cost_to_the_Public_0809.pdf.

33. Hanford, 534 F.3d at 995 . 
manufacture plutonium for military purposes. ${ }^{34}$ The government sought civilian contractors to operate the facility because "the government itself did not have the expertise or resources" to do so. ${ }^{35}$ E.I. DuPont was solicited by the government to operate the Hanford facility, and it initially refused. ${ }^{36}$ However, the government would not back down. ${ }^{37}$ The government urged E.I. DuPont that the project was extremely important and necessary for the war effort. ${ }^{38}$ E.I. DuPont eventually agreed in the name of "patriotism" and only accepted one dollar as payment. ${ }^{39}$ In 1946, General Electric ("GE") took over, also refusing compensation. ${ }^{40}$ The site emitted Iodine-131, which was known, even at that time, to have adverse effects on humans ${ }^{41}$ GE requested that the government change its regulations to allow for longer cooling times which would decrease the I-131 emissions. ${ }^{42}$ The government refused because it would not allow a decrease in plutonium production. GE continued to operate the facility in accordance with the set government standards. ${ }^{43}$

In the late 1980s, the DOE created the Hanford Environmental Dose Reconstruction Project ("HEDR") to estimate the possible exposure of radiation to those living around the Hanford facility. ${ }^{44}$ The project found that possibly harmful exposure occurred from 1944 to 1946 from the consumption of milk from cows that grazed in the area ${ }^{45}$ Upon the publication of the HEDR's report, litigation ensued under the Price-Anderson Act when individuals claiming various illnesses and property damaged sued operators of the Hanford facility for damages. ${ }^{46}$

\section{B. Arguments}

One of the most contested issues in the Hanford case was whether E.I. DuPont should be exempt from liability under the Price-Anderson Act according to the federal common law government contractor exception. The

\footnotetext{
34. Id. at 996

35. Id.

36. Id.

37. Id

38. Id.

39. Id.

40. Id. at 997 .

41. Id. at 996 .

42. Id. at 997 .

43. Id.

44. Id.

45. Id.

46. Id.
} 
plaintiffs sued the E.I. DuPont under Washington state tort law under a theory of strict liability because E.I. DuPont was engaged in an abnormally dangerous activity. ${ }^{47}$ E.I. DuPont sought to use the federal contractor defense to fight the application of strict liability. ${ }^{48}$

E.I. DuPont argued that the federal contractor defense should apply to them in this case and they should be dismissed as a defendant. The Court explained in Boyle v. United Technologies that this defense grants the government contractor the same immunity as if it were the government itself, so long as the contractor complied strictly with the terms of the government contract and regulations. ${ }^{49}$ E.I. DuPont argued that they could not be held strictly liable because they were following the federal government's orders and the emissions were within approved levels. ${ }^{50}$

\section{Court Decisions}

Initially, the federal district court for the Eastern District of Washington struck down the defense, holding that the Price-Anderson Act "displaced any such defense as a matter of law" because the defense could not be reconciled with the PAA. ${ }^{51}$ On appeal to the Ninth Circuit, the defendants raised the issue again whether they, as government contractors, could be exempted from liability using the federal contractor defense. ${ }^{52}$ The circuit court took a slightly different approach than the district court and held that the federal contractor defense could not be applied because the defense was not "well-established" at the time that the Price-Anderson Act was enacted and therefore, was not included as part of the liability scheme of the act. ${ }^{53}$ While, the circuit court agreed with E.I. DuPont that the contractor defense might extend to them as they did operate a military production facility pursuant to government specifications and under government orders, the court noted that it must also consider the Price-Anderson Act before applying the defense because it is unclear whether this Congressional Act preempts the federal common law doctrine of federal contractor immunity. ${ }^{54}$

In reaching its decision, the circuit court used language of the Supreme

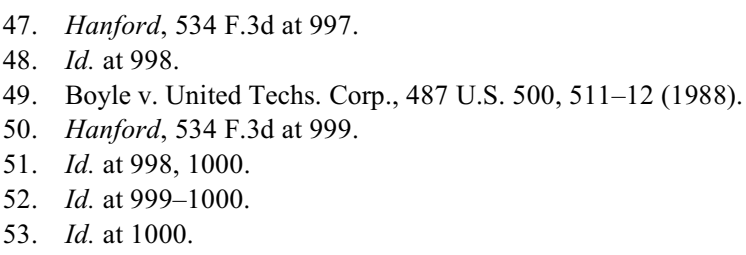


Court in United States v. Texas ${ }^{55}$ to establish the analysis for determining whether a federal statute preempts federal common law. ${ }^{56}$ The Court in United States $v$. Texas held that if a federal statute is enacted after a common law doctrine has been established, the federal common law will only be preempted if the statute directly addresses the common law principle. ${ }^{57}$ The rationale for this rule is that if the common law doctrine is "well-established," it must be assumed that Congress accounted for this doctrine in enacting the statute. ${ }^{58}$ The circuit court focused on the "well-established" element of the test and determined that the federal common law defense was not well-established when the Price-Anderson Act was enacted or when the Act was amended in $1988 .^{59}$ The court asserted that the defense was not recognized until Boyle, which was not decided until two months prior to amendment of the Price-Anderson Act in 1988. ${ }^{60}$ The court also stated that the origins of the federal contractor defense were irrelevant to the case at hand. ${ }^{61}$

The circuit court held that a seminal case regarding the federal contractor defense, Yearsley v. W. A. Ross Construction Co. ${ }^{62}$ did not apply because it did not extend to military contractors exercising a discretionary governmental function. ${ }^{63}$ In Yearsley, the court essentially deemed contractors agents of the government because they had no discretion and completely followed government specifications. ${ }^{64}$ The Ninth Circuit Court of Appeals, citing Justice Brennan's dissent in Boyle, held that the holding in Yearsley was limited and not meant to extend to "discretionary acts of those who perform service contracts." ${ }^{65}$

The court's issue with applying Yearsley to the Hanford case was that E.I. DuPont was hired to do new research for the government, and that research involved some discretion. ${ }^{6}$ However, other circuit courts have extended Yearsley to military contractors in the years before Boyle ${ }^{67}$ Still, the court

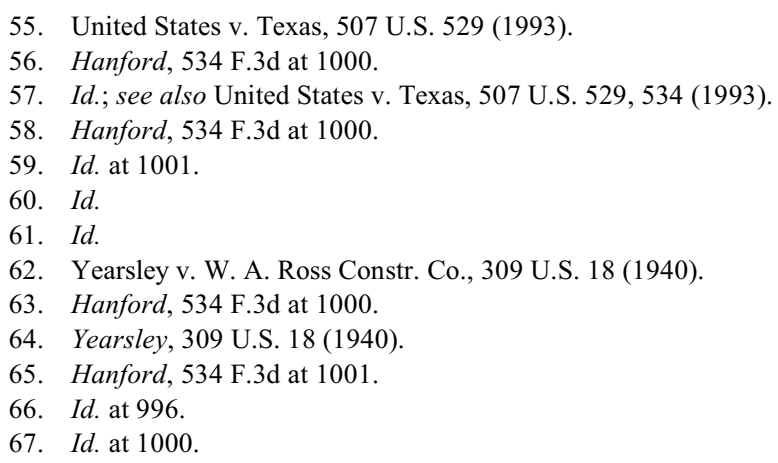


maintained that the scope of the defense was not well defined until Boyle and therefore held that it was not incorporated into the Price-Anderson Act. ${ }^{68}$

Additionally, E.I. DuPont faced another problem in applying this defense because the emissions at issue took place during 1944 to 1946, before GE took over and before the Atomic Energy Commission was created to regulate the production of plutonium. ${ }^{69}$ Without strict regulations, the defense is more difficult to apply. Admittedly, E.I. DuPont was essentially a researcher for the government and had a lot of discretion in their research and production of plutonium because this research had never been done before, and the concept was new. ${ }^{70}$ The government hired E.I. DuPont to pave the way in the field of plutonium production and nuclear weapons. ${ }^{71}$ The range of potential risks was unknown when E.I. DuPont began its work for the government. ${ }^{72}$ Regulations could not be created for something that did not exist at the time.

\section{Side-By-Side Comparison: Boyle and Hanford}

A side-by-side comparison with Boyle assists in understanding the precedent regarding the federal contractor defense.

Hanford parallels Boyle. First, there is a strong interest in "getting the Government's work done." "'3 In Boyle, United Technologies, the federal contractor, worked to design and make military helicopters for the government. ${ }^{74}$ After a pilot died in a helicopter crash due to some type of defect, his family sued United Technologies. ${ }^{75}$ The Court of Appeals reversed a judgment for the plaintiff, holding that United Technologies was not liable for a design defect under the military contractor defense. ${ }^{76}$ The Supreme Court vacated the judgment and remanded for the lower court to determine whether the evidence was sufficient to prove the military contractor defense. ${ }^{77}$ The Supreme Court held that to succeed under the military contractor defense, the design must be made according to governmental standards with minimal input

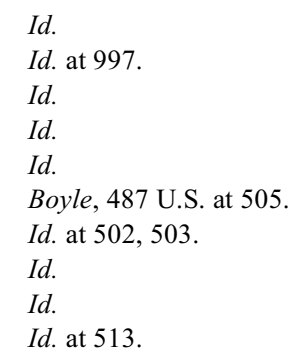


from the manufacturer and the manufacturer must have warned the government of any dangers known to the manufacturer. ${ }^{78}$

Obviously, military equipment is very important to the defense of the United States. However, the interest in getting the nuclear work done in Hanford was possibly even stronger. E.I. DuPont was recruited and eventually accepted a contract to research and produce plutonium to advance the ongoing war effort during World War Two ${ }^{79}$ with the idea that such research was necessary to defend the country against a possibly imminent attack. ${ }^{80}$ Both of these cases have a very strong federal interest: national defense. National defense is the responsibility of the federal government, ${ }^{81}$ and work on that federal interest may lead to use of the contractor defense.

In both Boyle and Hanford, the state-imposed duty of care was contradictory to the obligations under the government contracts. In Boyle, the duty imposed by the state to equip helicopters in certain ways for safety was directly contradictory to the standards set by the government contract in which the helicopters were to be made. ${ }^{82}$ Likewise, in Hanford, the state-imposed duty to not engage in abnormally dangerous activities clearly conflicts with the duty imposed by the government contract to produce plutonium for nuclear weapons, which are inherently dangerous themselves. ${ }^{83}$ Finally, there is an interest in allowing discretion on the part of the government in such areas as military equipment and national defense. ${ }^{84}$ It makes little sense in either of these cases to hold the contractor liable when the government would be immune from suit in both of these scenarios if it had simply not contracted out the job.

The interests in Hanford and Boyle are very similar in nature, circumstance and the need for application of the federal contractor defense. Therefore, Hanford should be decided the same way.

\footnotetext{
78. Id. at 514 .

79. Hanford, 534 F.3d at 996.

80. Id.

81. See U.S. Const. art. I, $\S 8$.

82. Boyle, 487 U.S. at 509.

83. Hanford, 534 F.3d at 997.

84. Boyle, 487 U.S. at 511.
} 


\section{E. The Federal Contractor Defense Should Apply in This Case}

\section{The Defense Was Established at the Time the Price-Anderson Act Was Enacted}

The Ninth Circuit may be correct in deciding that the federal contractor defense for military contracts was not solidified until the Supreme Court ruled in Boyle, but this does not necessarily mean that the defense did not exist and was not being used by other courts before Boyle. The analysis by the Ninth Circuit of the precedent regarding the federal contractor defense is superficial at best. The federal contractor defense was established and used in multiple courts in various capacities for both military and nonmilitary contracts before the Price-Anderson Act was amended in $1988 .{ }^{85}$ Before Boyle was decided, two cases had extended the federal contractor defense to nonmilitary contracts. ${ }^{86}$ In 1985, the Eleventh Circuit applied the defense in Burgess $v$. Colorado Serum Co. ${ }^{87}$ which did not involve a military contract. In that case, the court cited Yearsley ${ }^{88}$ and reasoned that,

Both the history of the defense and its general rationale lead us to the conclusion that it would be illogical to limit the availability of the defense solely to "military" contractors. If a contractor has acted in the sovereign's stead and can prove the elements of the defense, then he should not be denied the extension of sovereign immunity that is the government contract defense. ${ }^{89}$

The Seventh Circuit also applied the federal contractor defense to nonmilitary contracts in Boruski v. United States,${ }^{90}$ two years before the Supreme Court clearly established the defense in Boyle. ${ }^{91}$ In that case the Seventh Circuit applied the government contractor defense to claims arising out of a government vaccine program. ${ }^{92}$

85. Kelly A. Moore, Recent Development: The Third Circuit Expands the Government Contractor Defense to Include Nonmilitary Contracts, 72 WASH. U. L.Q. 1435, 1436-37 (Fall 1994).

86. Burgess v. Colorado Serum Co., 772 F.2d 844 (11 th Cir. 1985); Boruski v. United States, 803 F.2d 1421 (7th Cir. 1986).

87. Burgess v. Colo. Serum Co., 772 F.2d 844 (11th Cir. 1985).

88. Yearsley, 309 U.S. 18.

89. Burgess, 772 F.2d at 846 .

90. Boruski v. United States, 803 F.2d 1421 (7th Cir. 1986).

91. Boyle, 487 U.S. 500.

92. Boruski, 803 F.2d 1421. 
Not only was the federal contractor defense applied to nonmilitary contracts before 1988, but the court in Burgess ${ }^{93}$ also cited eight different cases in various jurisdictions between the years of 1982 and 1985 that applied the federal contractor defense to military contracts. ${ }^{94}$ This list demonstrates that regardless of whether the specifics of the defense were not completely outlined in one case until Boyle,${ }^{95}$ the defense was clearly established, used and applied by courts across the country well before Congress made the amendments to the PAA in 1988. Additionally, the idea of government or sovereign immunity stems back much further than the enactment of the Price-Anderson Act and it was not until 1948, with the passage of the Federal Tort Claims Act, that the federal government waived its immunity with regard to tort liability. ${ }^{96}$ In other words, there is historically a presumption against government liability, and where such liability exists, it was imposed by the government itself. With so much precedent, it is highly unlikely that Congress would overlook this defense or the ramifications of governmental immunity when passing the PAA or its amendments.

\section{Congressional Intent of the Price-Anderson Act Does Not Contradict the Application of Federal Contractor Defense}

The focus in the opinion of United States $v$. Texas ${ }^{97}$ was not on whether the federal common law was "well-established," but rather on the congressional intent in enacting the statute. ${ }^{8}$ However, the status of the federal common law was not in question in that case. Nevertheless, the Court emphasized a presumption of favoring the common law defense. ${ }^{99}$ The Court stated that unless the statute directly addresses the status of the federal common law or the statutory purpose is clearly contrary to the federal common law, the federal common law would not be preempted by the federal statute. ${ }^{100}$ The Court looked for any congressional intent to displace the common law and the overall purpose of the act in question. ${ }^{101}$ In order to follow the reasoning of the Supreme Court the Ninth Circuit should refocus

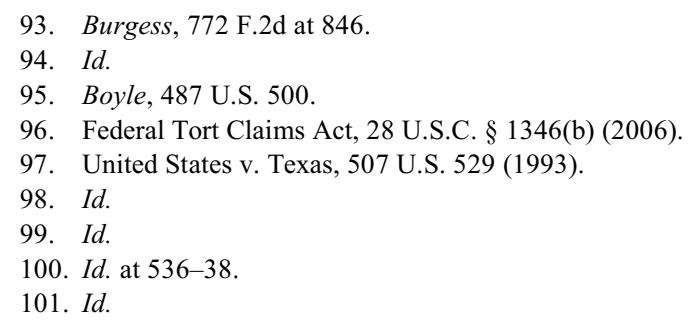


its analysis in Hanford. Instead of focusing on whether the federal law was "well-established," the court should have focused on the Congressional legislative intent and purpose behind the Price-Anderson Act.

The federal contractor defense is not necessarily contradictory to the Price-Anderson Act. The underground detonations clause of the PAA, Section 2210(d)(7), explicitly addresses defenses. ${ }^{102}$ This clause states that an indemnified contractor will be held liable for underground denotations and no "immunity or defense founded in the Federal, State or municipal character of the contractor or of the work to be performed under the contract shall be effective to bar such liability." 103 Again, the Ninth Circuit merely provided a superficial analysis of the issue. The court minimizes this clause in the PAA as "not clear." 104 However, by looking at the plain language of the clause, it is clear that Congress wanted to drive home the point that no matter what the circumstances, any person who engages in underground detonations will be held liable. ${ }^{105}$ This clause specifically refers to "contractors" and states that "no immunity or defense" may be used. ${ }^{106}$

The court also stated that "[e]ven assuming, however that Congress intended to ensure that the modern defense did not apply to underground detonations claims, it does not follow that Congress also intended, without saying so, that the defense would apply in all other situations." ${ }^{107}$ Clearly, Congress felt the need to specifically address defenses in regard to underground detonations for a reason, and it can reasonably be inferred that if a defense is explicitly banned in these circumstances, it is applicable in other circumstances unless otherwise specified.

Another section of the PAA also addresses governmental immunity. Section 2210(n) of the PAA addresses the "Waivers of Defenses and Judicial Procedures." 108 This section explicitly addresses a defense of governmental immunity, which can be incorporated into indemnity agreements with contractors. ${ }^{109}$

Regardless, the Ninth Circuit Court of Appeals held that the Price-Anderson Act does not directly address the federal contractor defense

102. 42 U.S.C. $\S 2210(d)(7)$.

103. Id.

104. Hanford, 534 F.3d at 1001-02.

105. 42 U.S.C. $\S 2210(d)(7)$

106. $I d$.

107. Hanford, 534 F.3d at 1002.

108. 42 U.S.C. $\$ 2210(\mathrm{n})$.

109. Id. 
and is essentially silent regarding the defense. ${ }^{110}$ Therefore, the court had to determine whether the defense would clearly conflict with the Act. ${ }^{111}$ A defense will be preempted only if it clearly conflicts with the Act. ${ }^{112}$ In this case, the court held that the federal contractor defense clearly conflicted with the PAA and was preempted. ${ }^{113}$

The purpose of the Price-Anderson Act, as initially enacted in 1957, was to cover the liability of commercial reactors. ${ }^{114}$ The Price-Anderson Act itself states its purpose in $\S 2012(\mathrm{i})$ :

In order to protect the public and to encourage the development of the atomic energy industry, in the interest of the general welfare and of the common defense and security, the United States may make funds available for a portion of the damages suffered by the public from nuclear incidents, and may limit the liability of those persons liable for such losses. ${ }^{115}$

"The main purpose of the Price-Anderson Act is to ensure the availability of a large pool of funds . . . to provide prompt and orderly compensation of members of the public who incur damages from a nuclear or radiological incidence not matter who might be liable." $" 116$

From the PAA's stated purpose, it does not appear that legal liability was the focus of the PAA. If the purpose of the Price-Anderson Act is to ensure that adequate insurance is provided so that the injured public can recover their damages quickly, then the federal contractor defense does not directly conflict with the PAA. Essentially, the Price-Anderson Act and the federal contractor defense cover two different spheres: insurance/funding for damages and legal liability. Since these spheres do not conflict, the second part of the United States $v$. Texas test is met and the federal law will not be preempted. ${ }^{117}$

Another point to consider is the fact that until 1988, the Price-Anderson Act did not require that DOE contractors be indemnified under the Act. ${ }^{118}$ This fact is further evidence of congressional intent in the Act. Clearly, the focus

110. Hanford, 534 F.3d 986.

111. United States v. Texas, 507 U.S. 529.

112. Id.

113. Hanford, 534 F.3d at 1002.

114. Eureka Cnty. Yucca Mountain Info. Office, The Price-Anderson Act, http://www.yuccamountain .org/price_anderson_act.htm (last visited on Nov. 19, 2009).

115. 42 U.S.C. § 2012(i) (2006).

116. Am. Nuclear Soc'y, supra note 21.

117. See generally United States v. Texas, 507 U.S. at 534.

118. Joseph Dinunno, Comments Prepared for Presentation to the Energy Facilities Contractors Group Executive Council Meeting, Mar. 21, 2009, available at http://www.hss.doe.gov/DepRep/1999/ ms99m31a.htm (last visited Jan. 28, 2011). 
of the PAA was on commercial reactors and their potential liability, not on federal DOE contractors and certainly not on contractors such as E.I. DuPont who were out of the picture long before the PAA was enacted. It was not until the 1988 amendments to the PAA that all DOE contracts were required to include indemnification schemes. ${ }^{119}$

According to precedent, Congressional silence regarding an issue in a piece of legislation is supposed to provide an assumption that Congress did not intend to "supplant the existing common law" unless there is a direct statement in the legislation regarding the common law. "'Congress's mere refusal to legislate with respect to" the federal contractor defense does not demonstrate an intent to overturn the federal common law. ${ }^{121}$ The Ninth Circuit, however, does not make this mandatory assumption in Hanford. Instead, it discards the language and basic purpose of the Price-Anderson Act, assumes that Congress was silent regarding the defense, and held that the federal contractor defense is clearly contradictory to the intent of the Price-Anderson Act and therefore the defense is preempted. ${ }^{122}$

This approach taken by the Ninth Circuit is casual and superficial. The fact that the statute does have some specific language regarding applicable defenses, coupled with the fact that the Price-Anderson Act was initially established to limit liability for private commercial reactors, demonstrates that Congress did not intend the federal contractor defense to be preempted, and the defense should be applied in the Hanford case.

\section{F. Other Issues to Consider Before Refusing to Apply the Federal Contractor Defense}

Timing must seriously be considered. E.I. DuPont signed on to run the Hanford facility for the federal government in the early 1940s as part of the "war effort." This was over ten years before the Price-Anderson Act was enacted. This ten year difference is very important for several reasons.

First, E.I. DuPont's work at the Hanford facility began and ended long before the PAA was enacted. Therefore, any emissions that caused later damages occurred long before the PAA was in force. Also, E.I. DuPont did not get the privilege of considering any liability scheme or government indemnification before accepting the job at the Hanford site. Additionally,

119. Department of Energy, supra note 27.

120. United States v. Texas, 507 U.S. at 534-35.

121. Id. at 535 .

122. Hanford, 534 F.3d at 1000-03. 
even if the PAA were in place when E.I. DuPont accepted the position, mandatory indemnification of contractors was not part of the PAA until 1988. E.I. DuPont had no reason to assume that it would be held strictly liable for the work it was to perform under the auspices of the federal government. Nuclear energy was not in the picture at this point, and any nuclear work in terms of weapons research was solely being done by the U.S. government. The latter point is still true today. Nuclear weapons research, production and use are not commercial in any aspect and are strictly controlled and performed by the federal government. The only difference today is that any DOE contractors would have indemnification clauses in their contracts. E.I. DuPont would never have gotten involved in the Hanford project but-for the urging of the government and the need of the government for contractors to perform nuclear research in the wake of war. From this perspective, it seems that the federal government should be solely responsible for any damages to the Hanford plaintiffs because the Hanford project was initiated by the government, and during the time that E.I. DuPont was involved, the project was overseen and run strictly for governmental purposes.

Second, as explained in the Department of Energy's report to Congress prior to the 2002 expiration of the Price-Anderson Act, "the Price-Anderson Act imposes strict liability by requiring the waiver of any defenses related to conduct of the claimant or fault of any person indemnified." ${ }^{23}$ These waivers are laid out in $\S 2210(\mathrm{n})$ of the PAA. This section states that the government may incorporate provisions into their contracts that mandate the waiver of defenses or government immunity. Today, government contractors working in similar situations to E.I. DuPont may be required to waive the federal contractor defense and expose themselves to strict liability under their contract. But, in return, they will be indemnified by the government for anything that should happen due to their work on the governmental contract. E.I. DuPont did not waive any defense or governmental immunity in its contract with the government. This clause in the new contracts is apparently meant to allow for imposition of strict liability under state tort law. ${ }^{124} \mathrm{But}$, if there is no waiver of a defense, such as in E.I. DuPont's case, governmental immunity or other defense should be permissible to rebut an imposition of strict liability. 


\section{CONCLUSION}

E.I. DuPont was not running the Hanford site for any commercial purpose. It did not even accept payment for its work because that work was done in the name of "patriotism." No commercial entity was involved in the site during the time in which the plaintiffs in the E.I. DuPont case were injured. Therefore, application of the federal contractor defense would clearly define the line between the federal government's responsibility in the nuclear industry and that of the commercial sector. Application of the federal contractor defense would clearly state, "this was the government's responsibility."

The 1988 amendment involving mandatory indemnification was important because it showed that the government is expected to step up and take responsibility for its conduct within the nuclear industry regardless of whether it does the work and research itself or whether it hires someone else to do it. Additionally, without such indemnification, the highly skilled contractors whom the government would seek to do any such work in the nuclear field would be very hesitant to sign on if they could be held responsible for doing what the government mandates they do according to their contract. And without these highly skilled contractors the government would be unable to proceed with much of its critical nuclear work.

The Ninth Circuit's decision to deny application of the federal contractor defense to this case was wrong. The defense clearly existed prior to the 1988 amendments to the Price-Anderson Act, the Act does not bar the defense, and application of the defense would not contradict the purpose of the Price-Anderson Act. E.I. DuPont should benefit from application of the federal contractor defense in this case. 